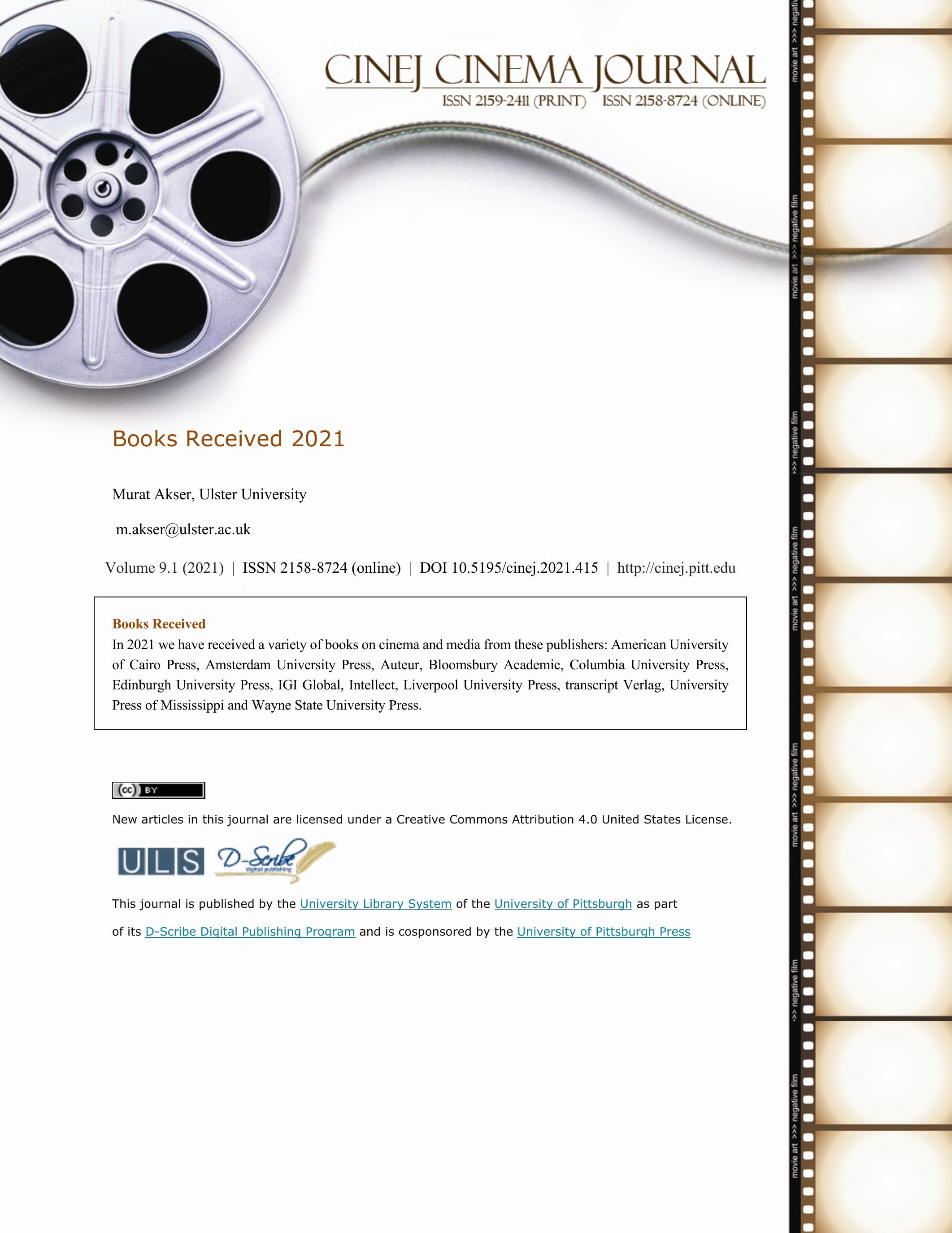




\section{Books received 2021}

\section{Murat Akser}

In 2021 we have received a variety of books on cinema and media from these publishers: American University of Cairo Press, Amsterdam University Press, Auteur, Bloomsbury Academic, Columbia University Press, Edinburgh University Press, IGI Global, Intellect, Liverpool University Press, transcript Verlag, University Press of Mississippi and Wayne State University Press.

\section{Bibliography:}

Alexander, L. D. (2021). Homicide: Life on the Street. Wayne State University Press.

Andersen, J. (2020). Stars and Silhouettes: The History of the Cameo Role in Hollywood. Wayne State University Press.

Baer, H. (Ed.) (2021). German Cinema in the Age of Neoliberalism. Amsterdam University Press.

Bannister, M. (2021). Eye Of The Taika: New Zealand Comedy and the Films of Taika Waititi. Wayne State University Press.

Baron, J., \& Fuhs, K. (Eds.). (2021). Kedi: A Docalogue. Routledge.

Bayrak, D., Dinç, E., Ekinci, Y., \& Reininghaus, S. (Eds.). (2020). Der deutsch-türkische Film: Neue kulturwissenschaftliche Perspektiven. transcript Verlag.

Bradbury-Rance, B. R. C. (2019). Lesbian cinema after queer theory. Edinburgh University Press.

Breger, C. (2020). Making Worlds: Affect and Collectivity in Contemporary European Cinema. Columbia University Press.

Delers, O., \& Sulzer-Reichel, M. (Eds.). (2020). Wim Wenders: Making Films that Matter. Bloomsbury Publishing USA. 
Elsaesser, T. (2021). The Mind-Game Film: Distributed Agency, Time Travel, and Productive Pathology. Routledge.

Ercolani, E. and M, Stiglegger. Cruising (Devil's Advocates). Liverpool University Press.

Fenwick, J. (Ed.). (2018). Understanding Kubrick's 2001: a space odyssey: representation and interpretation. Intellect Books.

Ezra, E. and C. Wheatley (Eds.). Shoe Reels: The History and Philosophy of Footwear in Film. Edinburgh University Press.

Filippo, M. S. (Ed.) (2021). After" Happily Ever After": Romantic Comedy in the Post-Romantic Age. Wayne State University Press.

Forrest, F. D. (2020). New Realism: Contemporary British Cinema. Edinburgh University Press.

Greenhill, P. (2020). Reality, Magic, and Other Lies: Fairy-Tale Film Truths. Wayne State University Press.

Hoel, J. (2020). Stalker (Constellations). Auteur.

Jones, N. (2020). Spaces mapped and monstrous: Digital 3D cinema and visual culture. Columbia University Press.

Kaklamanidou, B. (Ed.). (2020). New Approaches to Contemporary Adaptation. Wayne State University Press.

Kelley, N. M. (2018). Projections of Passing: Postwar Anxieties and Hollywood Films, 19471960. University Press of Mississippi.

Lanzoni, R. and E. Bowen (Eds.) (2020). The Cinema of Ettore Scola. Wayne State University Press.

LaRocca, D. (2021). The Thought of Stanley Cavell and Cinema: Turning Anew to the Ontology of Film a Half-Century after The World Viewed. Bloomsbury Academic. 
Luzzi, D. (Ed.) (2020). Italian cinema from silent screen to the digital image. Bloomsbury.

Maury, C. and D. Roche (Eds.). (2020). Women Who Kill: Gender and Sexuality in Film and Series of the Post-Feminist Era. Bloomsbury.

McElhaney, J. (2021). Luchino Visconti and the Fabric of Cinema. Wayne State University Press.

Mounir El-Shammaa, M. (2021). The National Imaginarium: A History Of Egyptian Filmmaking. American University of Cairo Press.

O'Meara, J. (2018). Engaging Dialogue: Cinematic Verbalism in American Independent Cinema. Edinburgh University Press.

Piotrowska, P. A. (Ed.). (2020). Creative Practice Research in the Age of Neoliberal Hopelessness. Edinburgh University Press.

Pomerance, P. M. (2018). Cinema, If You Please: The Memory of Taste, the Taste of Memory. Edinburgh University Press.

Rea, C. G. (2021). Chinese Film Classics, 1922-1949. Columbia University Press.

Redmond, S. (Ed.) (2021). Starring Tom Cruise. Wayne State University Press.

Richard, D. E. (2021). Film Phenomenology and Adaptation. Amsterdam University Press.

Richards, J. (2020). The Lost Worlds of John Ford: Beyond the Western. Bloomsbury.

Sanders, J. S. (2021). Batman: The Animated Series. Wayne State University Press.

Stojanova, C. and D. D. Duma, (Eds.) (2019). New Romanian Cinema. Edinburgh University Press.

Telotte, J. P., \& Duchovnay, G. (Eds.). (2021). Science Fiction Double Feature: The Science Fiction Film as Cult Text. Liverpool University Press. 
Tombul, I. (Ed.). (2021). Handbook of Research on Contemporary Approaches to Orientalism in Media and Beyond. IGI Global.

Williams, C. (2021). Mapping Fairy-Tale Space: Pastiche and Metafiction in Borderless Tales. Wayne State University Press.

Zaniello, T. (2020). The cinema of the precariat: The exploited, underemployed, and temp workers of the world. Bloomsbury Publishing USA. 